\title{
Anticipatory and reactive forms of blame avoidance: of foxes and lions
}

\author{
MARKUS HINTERLEITNER* AND FRITZ SAGER \\ Center of Competence for Public Management, University of Bern, Switzerland
}

\begin{abstract}
Blame avoidance behavior (BAB) encompasses all kinds of integrity-protecting activities by officeholders in the face of potentially blame-attracting events. Although considered essential for a realistic understanding of politics and policymaking, a general understanding of this multi-faceted behavioral phenomenon and its implications has been lacking to date. We argue that this is due to the lack of careful conceptualization of various forms of BAB. Crucially, the difference between anticipatory and reactive forms of BAB is largely neglected in the literature. This paper links anticipatory and reactive forms of $\mathrm{BAB}$ as two consecutive decision situations. It exposes dependence relationships between the situations that trigger $\mathrm{BAB}$, the rationalities at work, the resources and strategies applied by blame-avoiding actors, and the various consequences thereof. The paper concludes that anticipatory and reactive $\mathrm{BAB}$ are distinct phenomena that require specific research approaches to assess their relevance for the workings of polities.
\end{abstract}

Keywords: blame avoidance; elite behavior; political strategy; politics

The lion cannot protect himself from traps, and the fox cannot defend himself from wolves. One must therefore be a fox to recognize traps, and a lion to frighten wolves (Niccolò Machiavelli, The Prince).

\section{Introduction}

Blame avoidance behavior (BAB) encompasses all kinds of integrity-protecting activities by officeholders in the face of potentially blame-attracting events. It is increasingly common for scholars to scrutinize political decisions and their effects in order to establish whether, and to what degree, they have been caused by officeholders' motivation to avoid blame. By now, BAB is considered a widespread phenomenon that is essential for a realistic understanding of the nature and workings of political systems.

Heightened interest in the phenomenon of $\mathrm{BAB}$ and its implications across different fields of political science has also made the concept of blame avoidance increasingly fuzzy (König and Wenzelburger, 2014) and has produced a scattered and diffuse literature (Hood, 2011). One of the major complications in the study of

* E-mail: markus.hinterleitner@kpm.unibe.ch 
$\mathrm{BAB}$ is that different schools associate different phenomena with the term 'blame avoidance' and, consequently, study aspects that are only partly related when addressing this type of elite behavior and the consequences thereof. We argue that this is due to the lack of careful conceptualization of various forms of BAB. Crucially, the literature does not distinguish between BAB in anticipation of a blameworthy event and $\mathrm{BAB}$ as a reaction to a blameworthy event (Sulitzeanu-Kenan and Hood, 2005). While anticipatory BAB aims at keeping a potentially blameworthy event off the agenda and at preparing for blameworthy events, reactive $\mathrm{BAB}$ is about the public confrontation of blame. This strongly mimics Machiavelli's distinction in the opening quote where anticipatory $\mathrm{BAB}$ covers the fox's mission not to get caught and reactive BAB embodies the lion's resolution to defeat adversaries. Although this distinction is crucial for a general understanding of $\mathrm{BAB}$, it is still underdeveloped and remains largely neglected in the literature.

Starting from this insight, we conceptualize anticipatory and reactive BAB as two consecutive decision situations that officeholders face at various times throughout their careers. This conceptual distinction contributes to the literature on blame avoidance in three ways. First, it allows for the conceptual exploration and systematization of the different starting situations that trigger anticipatory and reactive $\mathrm{BAB}$, the rationalities at work, the specific resources and strategies applied by blame-avoiding actors, and the different consequences that are produced by anticipatory and reactive BAB (Johnson, 2014). Second, the distinction shows that scholars, when studying blame avoidance, essentially deal with two different phenomena that require distinct theoretical and empirical approaches for assessing their importance for the nature and workings of political systems. Finally, the distinction reveals starting points for empirical inquiry. Specifically, it holds implications for the existence of institutionalized blame avoidance arrangements across policymaking environments and the course of publicly visible blame games ${ }^{1}$ in different institutional environments and problem contexts. Taken together, this should enhance the empirical performance of the study of BAB.

The paper proceeds as follows: in the next section, we briefly delineate the behavioral tenets on which the study of $\mathrm{BAB}$ is based, outline the two main areas of research where $\mathrm{BAB}$ has been studied - comparative welfare state research and public policy/administration research - and associate these with anticipatory and reactive $\mathrm{BAB}$. The main section of the paper models anticipatory and reactive $\mathrm{BAB}$ as consecutive decision situations and illustrates which resources and strategies actors apply when resorting to these types of behavior. In the final section, the differences between these two types of $\mathrm{BAB}$ are explicated and the implications for future research on this phenomenon formulated.

\footnotetext{
1 The term blame game, as used in this article, does not necessarily imply a game theoretic foundation. Instead, it broadly refers to social interactions between at least two sets of actors, namely 'blame makers (those who do the blaming) and blame takers (those who are on the receiving end)' (Hood, 2011: 7).
} 


\section{Four worlds of blame avoidance}

$\mathrm{BAB}$ is generally explained with the motivation of officeholders to avoid losses that can result from blame (Weaver, 1986). For officeholders, losses concern the goals that they strive for and aim to protect when pursuing a career in public service. Scholars have used different concepts to describe the goals of politicians and other types of officeholders. While some studies have modeled politicians as mere office-seekers or vote maximizers (Downs, 1957; Mayhew, 1974), others have acknowledged that politicians, besides seeking re-election, also wish to advance their political agendas (Strøm, 1990; Pierson, 1994). More recent studies stress that officeholders seek to increase their institutional power, protect their reputation, and build a political legacy (Béland, 2007; Moynihan, 2012). The important point is that for all these goals, blame is dangerous. Blame can hamper (re-) election and career advancement, destroy a reputation or a legacy, and prevent officeholders from pursuing their policy goals.

When their goals are threatened by blame, officeholders usually prioritize their motivation to escape blame, since blame avoiding behavior in situations that mandate such behavior is a precondition for pursuing other policy motivations in situations that do not compel that behavior. Those who fail to avoid blame are likely to find themselves unemployed' (Weaver, 1986: 377-378, 1988). We can thus specify the behavioral preconditions that make officeholders engage in BAB: the inherent aversion to losses and goals threatened by blame.

The reason why BAB occurs in a particular situation is an event or issue that appears on the political agenda $\mathrm{a}^{2}$ and gives rise to blame directed at the actor. By shaking up the normal course of events, this 'focusing event' (Birkland, 1998) generates an action situation. Note that it is the perceived, and not necessarily the actual threat, associated with an event that creates an action situation and entices officeholders to engage in BAB (Wenzelburger, 2011, 2014). For example, a government enjoying widespread electoral support or operating in an environment in which the attribution of responsibility is comparatively difficult can well implement an unpopular policy without 'feeling threatened' by that policy (König and Wenzelburger, 2014). Actors may not feel threatened by an event if they consider their electoral or institutional position to be very safe.

While an explicit distinction between anticipatory and reactive $\mathrm{BAB}$ is absent in early work on the subject (Weaver, 1986), scholars have subsequently acknowledged that the need to avoid blame does not only arise ex-post, that is after the event has occurred and provoked blame. Under particular circumstances, actors can also anticipate the blameworthiness of an event and try to prepare for it in order

\footnotetext{
${ }^{2}$ In the following, we conceptualize the political agenda primarily in contrast to the media agenda. An issue is on the political agenda when officeholders can no longer ignore public or media attention but must somehow position themselves with regard to the issue (Kingdon, 1995; Walgrave and van Aelst, 2006; Baumgartner and Jones, 2010).
} 
to protect their goals (Arnold, 1990; McGraw, 1991). When an issue enjoys intensified public attention for a while, when policies force responsible officeholders to take unpopular decisions, or when officeholders are appointed by their superiors to deal with difficult policy problems, they quickly realize that they have to work under dangerous conditions and that damage may be significant if something goes wrong. From this, Sulitzeanu-Kenan and Hood (2005) have drawn the conclusion that one can differentiate between $\mathrm{BAB}$ in anticipation of a blameworthy event and $\mathrm{BAB}$ as a reaction to a blameworthy event. The authors stress that further research 'is needed to study more particular relationships between anticipatory and reactive motivations and officeholders' selection among [blame avoidance] strategies' (Sulitzeanu-Kenan and Hood, 2005: 19). Although this distinction is crucial for a thorough understanding of $\mathrm{BAB}$ and its implications, it remains largely neglected in the literature and, accordingly, its potential for the study of BAB has not yet been realized.

To structure the diverse and growing body of literature on blame avoidance, two sensible distinctions can be made. First, one can differentiate between the two main areas of research where $\mathrm{BAB}$ has been studied - comparative welfare state research and public policy/administration research (Hinterleitner, 2015), and then subdivide these strands of literature into work that studies anticipatory types and work that studies reactive types of $\mathrm{BAB}$.

Since the seminal work of Pierson $(1994,1996)$, the concept of blame avoidance has become well established in the literature on welfare state reform as a political strategy of imposing retrenchment against voter resistance. The conceptualization of BAB in this area of research draws on economic voting theory, which holds that politicians are held responsible at the ballot box by an electorate that retrospectively evaluates the economic performance of incumbents, following a simple reward-punishment logic (Fiorina, 1981; Arnold, 1990; Anderson, 2007). The causal chain linking the economic performance of politicians to voters' evaluation of that performance comprises four steps: (1) policies are enacted by politicians; (2) voters evaluate policies for their economic implications; (3) voters assign responsibility for the policies they evaluate; and (4) they vote accordingly. In this context, BAB is considered as a way to circumvent electoral punishment by influencing steps (2) and (3) (Hinterleitner, 2015). Scholars have examined the use of blame avoidance strategies for retrenchment purposes in various settings and have explored the conditions under which officeholders can successfully apply such strategies (Vis, 2009; Giger and Nelson, 2011; Wenzelburger, 2011; Mortensen, 2012; Jensen and Mortensen, 2014; Wenzelburger, 2014; Vis, 2016; Hinterleitner et al., 2016; Sager and Hinterleitner, 2016).

In public policy and administration research, BAB is treated in much broader terms and is considered a widespread phenomenon in the political sphere. Research has shown that there are many situations in which officeholders try to shield themselves from blame and that these are not limited to instances of retrenchment. $\mathrm{BAB}$ is studied in the policy process, in administrations and networks, after crises and failures as well as during the normal course of events (Bovens et al., 1999; 
Brändström and Kuipers, 2003; Hinterleitner and Sager, 2015; Hood, 2007; Boin et al., 2009; Hood et al., 2009; Hood, 2011; Moynihan, 2012; Mortensen, 2013b). Work on $\mathrm{BAB}$ in the welfare state domain deals mainly with anticipatory forms of $\mathrm{BAB}$, since politicians need to envisage voters' assessments of policies and design and frame the latter accordingly. However, reactive strategies that actors apply when they need to justify unpopular policies have also been studied (Mortensen, 2012; Vis, 2016; Wenzelburger and Hörisch, 2016).

Much research in the public policy and administration domain focuses on reactive $\mathrm{BAB}$, where an issue has already made its way onto the agenda and the relating blame, for instance during a media 'firestorm' (Hood, 2011), has to be dealt with. Anticipatory forms of $\mathrm{BAB}$ have also been examined in the public policy and administration domain. For example, scholars have studied the role of different types of arms-lengths institutional bodies in insulating, blame-deflecting institutional arrangements (Fiorina, 1982: 47, 1986; Horn, 1995). While Hood and Rothstein (2001) have examined blame-shifting organizational responses to demands for increased openness and transparency, Hood $(2007,2011)$ considered both anticipatory and reactive $\mathrm{BAB}$ in politics and organizational life. Table 1 provides an overview of the literature on $\mathrm{BAB}$ along the two dimensions outlined above.

Table 1. Overview of the literature on blame avoidance behavior (BAB)

\begin{tabular}{|c|c|c|}
\hline & Welfare state research & Public policy and administration research \\
\hline $\begin{array}{l}\text { Anticipatory } \\
\text { BAB }\end{array}$ & $\begin{array}{l}\text { Anticipation of electoral } \\
\text { punishment for retrenchment } \\
\text { (Pierson, 1994, 1996) } \\
\text { BAB as a means of pursuing } \\
\text { risky reforms (Vis, 2016) }\end{array}$ & $\begin{array}{l}\text { Arms-length institutional bodies that displace blame } \\
\text { (Fiorina, 1982; Horn, 1995) } \\
\text { Indexing provisions that limit budgetary } \\
\text { discretion (Weaver, 1988) } \\
\text { Opposition of policies that impose large and } \\
\text { direct costs (Arnold, 1990) } \\
\text { Blame-decreasing organizational responses to } \\
\text { demands for transparency (Hood and } \\
\text { Rothstein, 2001) } \\
\text { Responsibility-blurring governance vacuums } \\
\text { in multi-level systems (Bache et al., 2015) }\end{array}$ \\
\hline $\begin{array}{l}\text { Reactive } \\
\text { BAB }\end{array}$ & $\begin{array}{l}\text { Justification for retrenchment and } \\
\text { its effects (Mortensen, 2012; } \\
\text { Wenzelburger and Hörisch, } \\
\text { 2016) }\end{array}$ & $\begin{array}{l}\text { Blame-deflecting effects of political accounts } \\
\text { (McGraw, 1991) } \\
\text { Cabinet officials as 'lightning rods' (Ellis, 1994) } \\
\text { Blame management after crisis situations } \\
\text { (Bovens et al., 1999; Brändström and } \\
\text { Kuipers, 2003; Brändström et al., 2008; Hood et al., } \\
\text { 2009; Boin et al., 2010; Moynihan, 2012; } \\
\text { Brändström, 2015) } \\
\text { Commissions of inquiry for blame avoidance reasons } \\
\text { (Sulitzeanu-Kenan, 2010) } \\
\text { Blame attribution effects of public sector reforms } \\
\text { (Mortensen, 2013b) }\end{array}$ \\
\hline
\end{tabular}




\section{Conceptualizing BAB}

In the following, we build on existing work by conceptualizing anticipatory and reactive $\mathrm{BAB}$ as two distinct behavioral phenomena, exploring the dependence relationships between the events that trigger blame avoidance, the rationalities at work, the specific resources and strategies applied by blame-avoiding actors, and the different consequences produced by these types of blame avoidance. The conceptualization shows that both types of blame avoidance represent distinct behavioral phenomena that require specific research approaches to assess their relevance for the workings of polities.

\section{The fox game: anticipatory blame avoidance}

Anticipatory BAB in Machiavelli's metaphor is about avoiding traps. Hence, anticipatory forms of blame avoidance aim at keeping a potentially blameworthy event off the agenda and at preparing for blameworthy events.

As pictured in Figure 1, $A$ describes an event that can go either unnoticed $\left(A_{N B W}\right)$ or develop into a blameworthy event $A_{B W}$. Anticipatory BAB has two purposes: first, it is directed at decreasing the probability $p_{B W}$ so that a potentially blameworthy event does not appear on the political agenda and attract blame (with $p_{B W}+p_{N B W}=1$ ). To decrease $p_{B W}$, officeholders can make predominant use of what Hood (2011) has called policy strategies. Policy strategies are directed at minimizing individual liability by the careful selection and adaptation of operating routines and policies, such as the use of 'indexing provisions' that equip policies with discretion-limiting automatic adjustments for inflation (Weaver, 1988) or the formulation of policies with early-order benefits but widespread or postponed costs (Arnold, 1990). Lowering the visibility of retrenchment reforms serves the same



Figure 1 Anticipatory and reactive blame avoidance. 
purpose, since lower visibility decreases the probability that retrenchment will become politicized and thereby threatens the re-election prospects of politicians (Vis, 2016). In cases where the application of a controversial policy offers room for discretion, officeholders can try to decrease $p_{B W}$ by applying the policy in a stricter manner that pleases constituents. Moreover, politicians can try to reach deals behind closed doors to decrease the likelihood that a thorny issue makes it on the political agenda (Weaver, 2013). In Switzerland, for instance, where economic integration into the EU is a thorny topic, scholars have noted that international agreements increasingly happen behind closed doors and national laws and regulations are only indirectly adapted to the European context in order to avoid politicization (Jenni, 2015).

The second purpose of anticipatory $\mathrm{BAB}$ is to prepare for an eventual reactive blame game in case an event $A$, despite potential efforts to decrease $p_{B W}$, develops into a blameworthy event $A_{B W}$. Officeholders can apply agency strategies, which intend to shift responsibility or competency to others by means of delegation, diffusion, or postponement, to place themselves in a better position for an eventual reactive blame game (Hood, 2011). For instance, officeholders can try to 'pass the buck' to not directly politically accountable bodies such as central banks, independent regulatory agencies, or temporary commissions (Weaver, 2013). By delegating dicey policy decisions within an institution or shifting them to other institutional bodies, agencies, or contractors, officeholders can lower the probability of becoming associated with adverse outcomes when something goes wrong. A concrete example is officeholders responsible for the granting of early parole to potentially dangerous criminals, who frequently rely on expert commissions to back up decisions for which they bear political responsibility. When 'circling the wagons' by diffusing responsibility to as many policymakers as possible (Weaver, 1986), the amount of blame directed at one single actor can be lowered and more potential scapegoats become available during a reactive blame game. In short, agency strategies increase the future choice set of the responsible officeholder by widening the room in which blame can be deflected and diffused during an eventual reactive blame game.

The applicability of certain agency and policy strategies, as well as their prospects of success, depends on the nature of event $A_{B W}$ and the availability of specific resources. Not every event $A_{B W}$ necessarily allows the applicability of the full range of policy and agency strategies discussed above. For instance, particularly salient policies, which exist primarily as distant objectives for mass publics, have the potential to elicit rapt attention and powerful emotion, but their design features and material effects slip easily from public view because they lack concrete presence in most people's lives' (Soss and Schram, 2007: 122). Given an $A_{B W}$ of this sort, the effectiveness of policy and agency strategies that try to target these design features and material effects should be limited. Likewise, the visibility of particularly salient retrenchment reforms is unlikely to be significantly lowered by the careful adaptation of policy aspects. In other instances, the policy demands of powerful 
interest groups may be so strong that officeholders cannot prioritize their standing with the electorate (Hacker and Pierson, 2014).

As far as resources are concerned, officeholders must have at their disposal information and formal authority to successfully apply agency and policy strategies. Substantial information about one's responsibility sphere allows one to identify the events that contain considerable blame risks. Although this may be easy under particular circumstances, for example when an issue enjoys heightened public attention for a while, officeholders are often surprised by blameworthy events. And information alone does not suffice. Agency strategies aimed at shifting responsibility to others like 'buck-passing' or 'blame-shifting', or policy strategies aimed at modifying potentially blame-attracting aspects of policies can work only if actors possess the formal authority to do so. Sometimes, subordinates or officeholders working in adjacent policy areas may try to oppose the delegation or reshuffling of responsibilities (Hood, 2002). Hence, there may well be situations where officeholders are perfectly aware of a potentially blame-attracting event in their responsibility sphere, but do not have the formal authority to work on agency or policy dimensions and overcome the resistance of other actors.

When a potentially blameworthy event $A$ has been identified and resources to prepare for it are available, officeholders have to decide how much of their anticipatory resources they will use to try to prevent exactly this event from developing into a blameworthy one. Although not all of the resources are exhausted when deployed for event $A$, most of them cannot be used ad infinitum. Delegation arrangements, for example, can only be used sparsely, because not every task can be delegated away. Consequently, officeholders must carefully reason which events contain substantial blame risk and will concentrate the bigger share of their anticipatory resources on these events. The blame risk of an issue is primarily determined by the anticipated reactions of political and media elites and the public in case an issue makes it onto the political agenda. The stronger the expected feedback effect from the mass public, the more political and media elites will invest to exploit the issue and blame the responsible officeholder (Soss and Schram, 2007).

However, officeholders face a trade-off in that most anticipatory forms of BAB also come with forgone possibilities to claim credit when events go in a positive direction. Successful actions or decisions that were made less visible or delegated away are a forgone credit claiming opportunity, leading to a gradual erosion of political capital. For instance, when retrenchment reforms are appreciated (or at least accepted) by the electorate, lower visibility of these reforms limits the possibility of the actor to present herself as a decisive reformer. The degree of negativity bias in a given policy sector is thus liable to influence the individual investment in anticipatory BAB. The more politically charged and crisis prone a policy sector is, that is, in 'high-blame conditions' (Hood, 2011), the more resources the officeholder will invest in blame avoidance, and accordingly, the more blame avoidance arrangements such as delegation arrangements and public private partnerships should be in place. In other words, in a comparatively risky 
policymaking environment, officeholders should generally be more concerned with avoiding blame than with claiming credit (Nielsen and Baekgaard, 2015). Scholars should thus be able to find more institutionalized blame-diffusing policymaking arrangements in these environments, such as indexing provisions, independent regulatory bodies or 'fuzzy governance structures' (Bache et al., 2015).

\section{The lion game: reactive blame avoidance}

Reactive $\mathrm{BAB}$ in Machiavelli's terms is about frightening away wolves. Although reactive $\mathrm{BAB}$ does not necessarily encompass a resolute reaction by a blamed officeholder, Machiavelli's metaphor nevertheless points to the fact that reactive $\mathrm{BAB}$ is not any more about recognizing dangerous situations, but about the publicly visible confrontation of blame. Reactive $\mathrm{BAB}$ is displayed only if $A \rightarrow A_{B W}$, that is when - despite potential anticipatory blame-avoiding efforts - event $A$ develops into a publicly visible blameworthy event $A_{B W}{ }^{3}$ Given this new situation, reactive BAB aims at winning the blame game by increasing the probability $q_{N}$ with which event $A_{B W}$ develops into an event $A_{N}$ (no consequences), or in case the blame game is lost, tries to limit adverse political consequences such as resignation, demotion, or the loss of reputation (with $q_{c}+q_{N}=1$; see Figure 1). In contrast to anticipatory blame games that occur on the quiet before the politicization of an event, reactive blame games are characterized by their public visibility. Depending on the nature of $A_{B W}$, different actors are brought onto the scene and form the actor constellation of the reactive blame game.

The concept of 'arenas' is useful when structuring the relevant forms of interaction through which blamed actors need to 'forge pathways' to avoid blame during reactive blame games (Boin et al., 2010). The distinction between arenas provides important information about what types of actors are involved and in what environment interaction occurs. For instance, a blamed minister can be called to defend himself in a public inquiry, in parliament, or in the media. In each of these arenas, the minister faces different actors with different goals, different degrees of involvement, and different resources.

For the sake of illustration, we assume a conflict between one blame-avoiding actor (Actor 1; e.g. a politician blamed for a policy failure) and one adversary (Actor 2; e.g. the parliamentary opposition modeled as a corporate actor) in an arena (e.g. in parliament). Figure 2 pictures a schematic reactive blame game.

In contrast to the anticipatory blame game, the blamed politician will direct full attention to and invest all available resources to avoid $A_{B W}$ developing into $A_{C}$, especially when the expected costs associated with $A_{C}$ are serious (significant

\footnotetext{
${ }^{3}$ Although reactive blame games can start without a preceding anticipatory blame game, taking a blamed actor by surprise, both types of blame games can be modeled as consecutive games for two reasons: first, the goal of the anticipatory blame game is to avoid a reactive blame game. Second, anticipatory blame avoidance can enhance the chances of prevailing in a reactive blame game.
} 


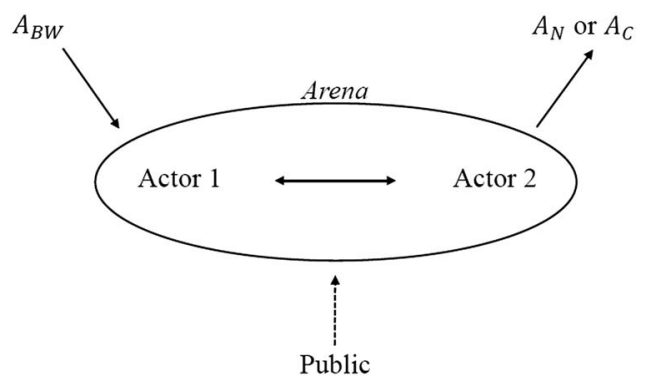

Figure 2 Set-up of the reactive blame game.

reputational damage, potential loss of career, etc.). There is thus no trade-off like in the anticipatory blame game. During reactive blame games, blamed actors mainly have to rely on different types of blame management strategies (Bovens et al., 1999; Brändström et al., 2008). Agency and policy strategies are less useful during reactive blame games, since they usually cannot be put in place on an ad boc basis, or at least lack credibility if implemented swiftly. An important type of blame management strategies are presentational strategies (Hood, 2011), which intend to shape public impressions and frame the public debate about $A_{B W}$. The literature contains detailed descriptions and categorizations of presentational strategies that actors can apply during reactive blame games, ranging from justification (McGraw, 1991; Green-Pedersen, 2002), discourse (Schmidt, 2001), rhetoric (Cox, 2001), and framing (Ross, 2000; Druckman, 2001; Boin et al., 2009), to persuasion and priming (see König and Wenzelburger 2014 for an overview). Moreover, blamed actors can try to demonstrate commitment by launching inquiries (Sulitzeanu-Kenan, 2010) or propose symbolic reforms to resolve $A_{B W}$ and tackle its consequences (Brändström, 2015). The strategic demotion of subordinate officials can also be used to stymie adversaries (Brändström and Kuipers, 2003; Dewan and Dowding, 2005).

The success of these strategies again depends on the disposability of several resources. As with the anticipatory blame game, information and institutional power play a crucial role. If actors enjoy particular advantages 'when it comes to dispersing and withholding information' (Brändström and Kuipers, 2003: 305), such as privileged access to the media, they can present events in a beneficial way. When they have the formal authority to launch inquiries or symbolic reforms, they can demonstrate commitment. For officeholders frequently exposed to public scrutiny, argumentative skills are particularly important. They help to shape public perceptions. Another resource that allows officeholders to influence public perceptions in their favor is their prior popularity and the corresponding level of trust they enjoy. Both trust in government (Hood, 2011) and the popularity of specific (blamed) actors (Page et al., 1987) touch on the 'credibility of the source' (Druckman, 2001), a concept widely used in the framing literature. To determine 
whether officeholders are trustworthy and possess knowledge of the subject matter, the public resorts to 'source cues', that is proxies that help to assess the credibility of the source (Mondak, 1993; Lyons and Jaeger, 2014). Both trust in government and the prior popularity of specific officeholders can be considered as source cues: a popular officeholder enjoys comparably more public confidence and credibility and should therefore be more successful at selling her frame to the public. Voters also tend to be more forgiving if a responsibility admission or an excuse comes from a popular and trusted actor. Another resource, useful for reactive BAB, results from group membership. Officeholders who can rely on support from their party or their head of government should be more successful during a reactive blame game. Blamed ministers, for instance, heavily depend on support from their head of government. If the latter decides to sacrifice the minister as a means of increasing government popularity (Dewan and Dowding, 2005), negative consequences can hardly be avoided. Finally, an important resource that enhances the applicability and success of blame management strategies are the blame avoidance efforts undertaken during a preceding anticipatory blame game. If the blamed Actor 1 has invested a considerable amount of resources in anticipatory blame avoidance arrangements before, he or she will now be in a better position to avoid blame. Anticipatory blame avoidance efforts widen the room for maneuver of the blamed actor by limiting the blame attributed to the actor and provide additional possibilities to displace or diffuse blame by increasing the number of available scapegoats (Bartling and Fischbacher, 2012). Strategies such as responsibility denial are more effective if the blame-avoiding Actor 1 can credibly point to other actors for the events at hand.

In the reactive blame game, Actor 2 (e.g. the parliamentary opposition) needs to decide how much of its resources, for example, in the form of media access or time allotted for speaking in parliament, it devotes to blaming its adversary, while foregoing the possibility to emphasize own achievements. The amount of blame generated by Actor 2 is influenced by both the frequency of blameworthy events, and their timing. When blameworthy events are frequent, it makes sense to concentrate resources on just a few (especially promising) ones, so as not to wear out upsetting accusations. ${ }^{4}$ Moreover, when a blameworthy event unfolds shortly before an election, it is particularly promising to concentrate resources on this event, since it can be portrayed as a convincing reason for change (Boin et al., 2009).

In order to fully conceptualize the reactive blame game, one must consider not only the resources and strategies of Actor 1 and Actor 2, but also the reaction of the public, as the reactive blame game, unlike the anticipatory blame game, is publicly visible. The reaction of the public can be captured by referring to the constitutive elements of blame. For public blame to develop, two aspects need to come together: a perception of loss or harm and a perceived responsibility for the loss or harm

\footnotetext{
${ }^{4}$ For instance, repeated demands to resign will lose their power when used excessively.
} 
(Hood, 2011). That is, only with a clear attribution of responsibility can a perception of loss or harm develop into target-oriented blame. Both elements of blame are influenced by a number of issue-related and country-specific contextual factors (Hinterleitner and Sager, 2015).

The perception of loss or harm depends on the nature of event $A_{B W}$ and its salience. Salience is high when (policy) losses are concentrated and immediate, that is when event $A$ erupts into a dramatic focusing event $A_{B W}$ (Jacobs and Weaver, 2015 ), or when core public values have been threatened (Brändström and Kuipers, 2003) and the social cleavages regarding these values are low (Sulitzeanu-Kenan and Sheffer, 2011). The more salient an issue is to the wider public, the more interest and attention it will command, the more the media will report on it, the more blamed actors will come under scrutiny, and the more likely it will be that specific interest groups mobilize resources to tackle the issue (Jacobs and Weaver, 2015). Another factor that influences the perception of loss is the type of media coverage $A_{B W}$ receives. Media systems that traditionally exhibit a more personalized and aggressive coverage style should very often inflate real losses. Perceived loss thus exerts a positive influence on the aggregate level of blame.

The second aspect of blame, perceived responsibility, depends on the ease with which the wider public can see through the blame game and assign responsibility. This can be captured by determining the factors which influence the 'clarity of responsibility' both in the political system in which the blame game is played out and in the policy sector where $A_{B W}$ has emerged (Powell and Whitten, 1993; Anderson, 2007). Relevant characteristics of the political system are the institutional fragmentation and the role and significance of parties. In more decentralized countries like the United States, Germany, or Switzerland more actors should be involved in the blame game than in more centralized countries like the United Kingdom, as subnational units possess more competencies in policymaking and implementation. Given that more actors from lower levels of government are involved, blame games should be situated further away 'from the top', with more wiggle room for top-level officeholders. This points to a more unclear actor set-up with multiple actors somehow involved in the blame game, spanning additional arenas such as federal parliaments or local media. Under these circumstances, responsibility can be more easily diffused and blame is more difficult to attribute to specific actors. In addition, in countries like the United Kingdom, Germany, or Switzerland, where party discipline is higher than in countries like the United States, responsible officeholders should be better insulated from blame as individual actors have fewer incentives to blame others and deviate from the party line in order to appeal to their voters. Instead, strong party images and party discipline should result in more government- and party-centered BAB, with individual actors being less directly exposed to blame (Weaver, 1986).

With regard to the policy sector where $A_{B W}$ has emerged, the complexity of collaborative structures influence the ease with which blame can be pinned down. The more complex the structures around $A_{B W}$ and the more actors involved, the 
Table 2. Contextual factors influencing the clarity of responsibility

\begin{tabular}{ll}
\hline \hline Political system characteristics & Policy sector characteristics \\
\hline Institutional fragmentation & Complexity of collaborative structures \\
Role/significance of political parties & Degree of involvement \\
\hline \hline
\end{tabular}

more difficult it is to see through the blame game from outside. Complex structures should thus increase the room for maneuver of the blame-avoiding actor (Hood, 2011; Hobolt et al., 2013). Concrete examples where the responsibility-diffusing quality of complex collaborative structures becomes decisive are blame games triggered by delayed and expensive government projects. Such projects often encompass a considerable number of public and private actors somehow involved in the implementation process who shift blame around, making it difficult for observers to clearly assign responsibility. Another related factor that influences perceived responsibility is the degree of direct involvement of politically responsible officeholders. The more they are involved in specific policy issues, the higher the probability that 'they are to be held liable for poor performance or for policy changes that impose losses' (Weaver, 1986: 390), as they cannot easily distance themselves from detrimental outcomes (see Table 2 for an overview).

The aggregate level of public blame directed at the blame-avoiding actor - buttressed and/or mitigated by contextual factors - exerts an additional influence on the blame game over and above the influence already characterized by the actors involved and their respective resources and strategies. The perceived loss of and the perceived responsibility for $A_{B W}$ predetermine the 'wiggle room' of blame-avoiding actors in a particular arena, which they will try to exploit in the best possible way to avoid detrimental political consequences $\left(A_{C}\right)$.

The assessment of resources and strategies applied by Actor 1 and Actor 2, and the reaction of the public, allow us to hypothesize whether 'agency' or 'structure' conditions will be more decisive for the course of the reactive blame game. By tendency, in settings where the perceived loss is significant and/or the attribution of blame is easy to make, it should be more likely that blamed actors face adverse political consequences, regardless of their individual blame avoidance efforts. On the contrary, in settings where the salience of an issue is lower and/or the attribution of blame is more difficult, blamed actors should have more wiggle room and, accordingly, their individual actions and capabilities should be more decisive for the course of the reactive blame game.

\section{Implications for the study of $B A B$}

Modeling anticipatory and reactive $\mathrm{BAB}$ as consecutive games emphasizes the dependence relationships between the different situations that trigger blame 
avoidance, the particular rationalities at work when blame avoidance is displayed, the specific resources and strategies applied by blame-avoiding actors, and the different consequences that are produced by these types of blame avoidance. This endeavor clearly shows that scholars, while drawing on common ground when studying anticipatory and reactive forms of BAB, nevertheless deal with two distinct behavioral phenomena that ought not to be conflated. Anticipatory and reactive $\mathrm{BAB}$ are based on different calculations, require different types of resources and strategies, display different dynamics and thus have different implications for our understanding of elite behavior. Moreover, both types of BAB face distinct theoretical and empirical challenges.

\section{Actor calculations}

Anticipatory and reactive $\mathrm{BAB}$ are based on different calculations. While anticipatory $\mathrm{BAB}$ is based on the identification of potentially blameworthy events in one's responsibility sphere and the careful allocation of resources to modify agency and policy dimensions, reactive BAB takes the form of an 'all in' game where blamed actors try everything in their power to protect their goals.

\section{Strategies}

During anticipatory blame games, officeholders make predominant use of policy and agency strategies. Reactive BAB relies more on blame management strategies, since policy and agency strategies usually cannot be put in place on an ad hoc basis and lack credibility if implemented swiftly.

\section{Resources}

The relative importance of skills and resources to successfully avoid blame differs between an anticipatory and a reactive blame game. For anticipatory BAB, the capability to identify potentially threatening events in advance and the institutional power to modify agency and policy dimensions are most important. For reactive BAB, next to information and institutional power, argumentative skills and reputation to frame public opinion and blame-insulating group membership are crucial.

\section{Dynamics}

Both blame games have a different set-up and display distinct dynamics. Anticipatory blame games are much less visible and involve fewer interactive parts than reactive blame games, as responsible officeholders deal solely with the potential resistance to acts of diffusion and delegation. Reactive blame games, on the contrary, are more visible and interactive since various actors, ranging from political elites, media, and interest groups, to the general public, are brought to the scene by a publicly visible, blame-generating issue. 


\section{Relevance}

Both types of blame avoidance have distinct implications for the understanding of elite behavior and its consequences for the nature and workings of political systems. The implications of anticipatory $\mathrm{BAB}$ are predominantly for institutional and policy design, as anticipatory $\mathrm{BAB}$ can translate into blame-deflecting institutional arrangements and policy design that may alter the institutional set-up of policy sectors and influence the effectiveness of policies. The implications of reactive BAB concern the understanding of how political systems handle public blame in the political sphere, whether they can cope with it and fulfill their basic functions during blame games or whether reactive blame games lead to political polarization and policy stalemate.

\section{Theoretical and empirical challenges}

Research on both types of $\mathrm{BAB}$ faces distinct theoretical and empirical challenges. Research on anticipatory $\mathrm{BAB}$ needs to establish when exactly and how often officeholders make anticipatory blame-avoidance calculations and whether, and how, these calculations manifest themselves in policy aspects and institutional structures that can be utilized for blame avoidance purposes. While empirical findings suggest that public sector reforms can indeed lower blame attribution in the media (Mortensen, 2013a, b), an important question remaining is the degree to which such reforms are actually driven by blame avoidance efforts in the first place. The conceptualization of the anticipatory blame game holds two important implications for this research problem. First, it reveals that blamed officeholders can rely both on fragmented structures deliberately created for the purpose of blame avoidance and on structures already in place. Second, the conceptualization suggests that blameworthy events do not occur or occur very rarely if anticipatory $\mathrm{BAB}$ is very effective. Thus, by testing the blame-deflecting and blame-decreasing effects of fragmented structures, we cannot answer the question as to how often officeholders "consciously set out to deploy the "problem of many hands" as a strategy for diluting their responsibility or distancing themselves from a knotty political dilemma' (Bache et al., 2015: 84). The question as to how dominant the motivation of officeholders to avoid and prepare for blameworthy events actually is cannot be answered in this way, but must be targeted separately.

Research on reactive BAB faces two specific research problems. First, it needs to establish whether and how the complex dynamics within blame games are influenced by country-specific and issue-related contextual factors. Without additionally considering the context in which $\mathrm{BAB}$ is displayed, it should be difficult to derive clear, evidence-based conclusions about its effects. The conceptualization of the reactive blame game suggests that both the perceived loss of and the perceived responsibility for an issue are buttressed or mitigated by contextual factors. Hence, the success of strategies working on these dimensions crucially depends on the specific configuration of contextual factors. Second, further research needs to assess whether, and how, reactive blame games translate into personal, political, and 
system change, that is whether they fulfill a spotlight function and open a window of opportunity or represent mere acts of political entertainment.

\section{Empirical strategies}

The specific challenges outlined above make it clear that both types of blame avoidance require distinct research strategies. Research on anticipatory BAB starts at a disadvantage, since anticipatory BAB is less visible and, thus, more difficult to observe than reactive $\mathrm{BAB}$. Studies on reactive $\mathrm{BAB}$ can directly examine actor behavior, while work attempting to assess the importance of anticipatory forms of BAB needs to take a detour and infer BAB from other developments. To establish the causal relevance of anticipatory blame avoidance efforts for the institutional design of political systems and the design of policies, the conceptualization of the anticipatory blame game suggests that these efforts depend on the anticipated blame risk of events in the responsibility sphere of an actor. This insight discloses a way of measuring the pervasiveness of institutional arrangements associable to efforts of blame avoidance. While it is difficult to measure the development of blame avoidance arrangements over time (Hood, 2011), comparing them across sectors that vary in their blame risk offers possibilities to causally relate institutional and policy developments to efforts of blame avoidance and to measure the effects of anticipatory BAB on institutional and policy design. Another strategy is to process trace backward from institutional settings to those anticipatory blame avoidance efforts which created them in the first place (Pal and Weaver, 2003). With regard to the study of reactive BAB, scholars need to assess the influence of contextual factors on various aspects of blame games - such as the actor constellation, the strategies applied, or the degree of personalization. This can be done by comparing reactive blame games across political systems and problem contexts. Table 3 summarizes major differences between anticipatory and reactive BAB.

\section{Conclusion}

It is increasingly common for scholars to associate various political developments with officeholders' motivation and efforts to avoid blame. BAB is said to influence the nature and workings of political systems in many ways. However, the concept of blame avoidance is often applied without giving full consideration to the overall picture. This article has shown that, when studying blame avoidance, scholars essentially deal with two different phenomena that have distinct implications for the understanding of elite behavior and require distinct research approaches to assess their overall relevance. To emphasize similarities and differences between these two types of $\mathrm{BAB}$, the present article has conceptualized anticipatory and reactive $\mathrm{BAB}$ as consecutive decision situations that officeholders face at times throughout their careers. This has allowed us to explicate dependence relationships between the situations that trigger $\mathrm{BAB}$, the rationalities at work, the resources and strategies applied by blame-avoiding actors, and the various consequences thereof. 
Table 3. Differences between anticipatory and reactive blame avoidance

\begin{tabular}{|c|c|c|}
\hline & Anticipatory blame game & Reactive blame game \\
\hline $\begin{array}{l}\text { Actor } \\
\text { calculations }\end{array}$ & $\begin{array}{l}\text { Careful trade-off calculus; identification } \\
\text { of potentially blame-attracting events }\end{array}$ & $\begin{array}{l}\text { Full attention (and resources) devoted to } \\
\text { particular blameworthy event }\end{array}$ \\
\hline Strategies & Policy and agency strategies & Blame management strategies \\
\hline Resources & $\begin{array}{l}\text { Information to identify potentially } \\
\text { blameworthy events; institutional } \\
\text { power to change agency and/or } \\
\text { policy dimensions }\end{array}$ & $\begin{array}{l}\text { Information and institutional power, } \\
\text { argumentative skills, popularity, and trust } \\
\text { to frame debate; group membership; } \\
\text { anticipatory blame avoidance efforts }\end{array}$ \\
\hline Dynamics & $\begin{array}{l}\text { Invisible; less interactive (but potential } \\
\text { opposition against policy and agency } \\
\text { strategies) }\end{array}$ & $\begin{array}{l}\text { Visible; more interactive as actors are } \\
\text { attracted by blameworthy event }\end{array}$ \\
\hline Relevance & $\begin{array}{l}\text { Impact of anticipatory BAB on } \\
\text { institutional and policy design }\end{array}$ & $\begin{array}{l}\text { Impact of reactive blame game on personal, } \\
\text { policy, and system change }\end{array}$ \\
\hline $\begin{array}{l}\text { Theoretical } \\
\text { and empirical } \\
\text { challenges }\end{array}$ & $\begin{array}{l}\text { When and how often calculation is made; } \\
\text { when and how calculation guides } \\
\text { behavior and translates into institutional } \\
\text { and policy design }\end{array}$ & $\begin{array}{l}\text { Influence of contextual factors on reactive } \\
\text { blame games and resulting consequences }\end{array}$ \\
\hline $\begin{array}{l}\text { Empirical } \\
\text { strategies }\end{array}$ & $\begin{array}{l}\text { Comparison of institutional blame-avoidance } \\
\text { arrangements across contexts; read back } \\
\text { from institutional design to anticipatory BAB }\end{array}$ & $\begin{array}{l}\text { Context-sensitive comparison of reactive } \\
\text { blame games across political systems and } \\
\text { problem contexts }\end{array}$ \\
\hline
\end{tabular}

The conceptual distinction put forward in this paper has illuminated the specific empirical puzzles the study of BAB needs to solve. For the study of anticipatory forms of $\mathrm{BAB}$, it is most important to find ways to establish whether, and to what degree, institutional arrangements that can be utilized for blame avoidance have been deliberately contrived for this purpose and to what degree the design and implementation of policies is influenced by anticipatory BAB. If so, the much debated declining responsiveness of political systems to various kinds of problems must also be discussed in the light of policymaking arrangements deliberately designed for reasons of blame avoidance (Streeck and Schäfer, 2013; Hood and Dixon, 2015). For the study of reactive forms of BAB, it is important to compare visible blame games across different institutional settings and problem contexts to establish how the 'political treatment of failure' within reactive blame games interferes with accountability mechanisms and influences policy and system change.

In any case, a more careful and systematic look at the behavioral processes underlying different types of BAB should help to advance our understanding of 'how political actors make decisions under risk' (Mercer, 2005: 18). Conceptualizing anticipatory and reactive forms of $\mathrm{BAB}$ constitutes an important step in creating a more realistic understanding of officeholders, their behavior, and the consequences this behavior may have. 


\section{Acknowledgments}

The authors thank Thurid Hustedt, David Kaufmann, Leslie A. Pal, Doina Radulescu, R. Kent Weaver, the editors of EPSR, and the four anonymous referees for their valuable comments. This research was funded by the Swiss National Science Foundation (Grant Number 100018_153111).

\section{References}

Anderson, C.J. (2007), 'The end of economic voting? Contingency dilemmas and the limits of democratic accountability', Annual Review of Political Science 10(1): 271-296.

Arnold, R.D. (1990), The Logic of Congressional Action, New Haven, CT: Yale University Press.

Bache, I., I. Bartle, M. Flinders and G. Marsden (2015), 'Blame games and climate change: accountability, multi-level governance and carbon management', The British Journal of Politics \& International Relations 17(1): 64-88.

Bartling, B. and U. Fischbacher (2012), 'Shifting the blame: on delegation and responsibility', The Review of Economic Studies 79(1): 67-87.

Baumgartner, F.R. and B.D. Jones (2010), Agendas and Instability in American Politics, Chicago: University of Chicago Press.

Béland, D. (2007), 'Insecurity and politics: a framework', The Canadian Journal of Sociology 32(3): 317-340.

Birkland, T.A. (1998), 'Focusing events, mobilization, and agenda setting', Journal of Public Policy 18(1): 53-74.

Boin, A., J. Hart, A. McConnell and T. Preston (2010), 'Leadership style, crisis response and blame management: the case of Hurricane Katrina', Public Administration 88(3): 706-723.

Boin, A., P. 't Hart and A. McConnell (2009), 'Crisis exploitation: political and policy impacts of framing contests', Journal of European Public Policy 16(1): 81-106.

Bovens, M., J. Hart, S. Dekker and G. Verheuvel (1999), 'The politics of blame avoidance: defensive tactics in a Dutch crime-fighting fiasco', in H.K. Anheier (ed.), When Things Go Wrong: Organizational Failures and Breakdowns, Thousand Oaks, CA: SAGE Publications, pp. 123-148.

Brändström, A. (2015), 'Crisis accountability: ministerial resignations in Sweden', Scandinavian Political Studies 38(3): 301-320.

Brändström, A. and S. Kuipers (2003), 'From "normal incidents" to political crises: understanding the selective politicization of policy failures', Government and Opposition 38(3): 279-305.

Brändström, A., S. Kuipers and P. Daléus (2008), 'The politics of tsunami responses: comparing patterns of blame management in Scandinavia', in A. Boin, A. McConnell and P. 't Hart (eds), Governing After Crisis: The Politics of Investigation, Accountability and Learning, Cambridge and New York: Cambridge University Press, pp. 114-147.

Cox, R.H. (2001), 'The social construction of an imperative: why welfare reform happened in Denmark and the Netherlands but not in Germany', World Politics 53(3): 463-498.

Dewan, T. and K. Dowding (2005), 'The corrective effect of ministerial resignations on government popularity', American Journal of Political Science 49(1): 46-56.

Downs, A. (1957), 'An economic theory of political action in a democracy', Journal of Political Economy 65(2): 135-150.

Druckman, J.N. (2001), 'On the limits of framing effects: who can frame?', The Journal of Politics 63(4): 1041-1066.

Ellis, R. (1994), Presidential Lightning Rods: The Politics of Blame Avoidance, Lawrence, KS: University Press of Kansas.

Fiorina, M.P. (1981), Retrospective Voting in American National Elections, New Haven, CT: Yale University Press.

Fiorina, M.P. (1982), 'Legislative choice of regulatory forms: legal process or administrative process?', Public Choice 39(1): 33-66. 
Fiorina, M.P. (1986), 'Legislator uncertainty, legislative control, and the delegation of legislative power', Journal of Law, Economics, and Organization 2(1): 33-51.

Giger, N. and M. Nelson (2011), 'The electoral consequences of welfare state retrenchment: blame avoidance or credit claiming in the era of permanent austerity?', European Journal of Political Research 50(1): 1-23.

Green-Pedersen, C. (2002), The Politics of Justification: Party Competition and Welfare-State Retrenchment in Denmark and the Netherlands from 1982 to 1998, Amsterdam: Amsterdam University Press.

Hacker, J.S. and P. Pierson (2014), 'After the "Master Theory": downs, Schattschneider, and the rebirth of policy-focused analysis', Perspectives on Politics 12(3): 643-662.

Hinterleitner, M. (2015), 'Reconciling perspectives on blame avoidance behaviour', Political Studies Review, doi: 10.1111/1478-9302.12099.

Hinterleitner, M. and F. Sager (2015), 'Avoiding blame - a comprehensive framework and the Australian home insulation program fiasco', Policy Studies Journal 43(1): 139-161.

Hinterleitner, M., F. Sager and E. Thomann (2016), 'The politics of external approval: explaining the IMF's evaluation of austerity programmes', European Journal of Political Research, doi: 10.1111/14756765.12142.

Hobolt, S.B., J. Tilley and J. Wittrock (2013), 'Listening to the government: how information shapes responsibility attributions', Political Behavior 35(1): 153-174.

Hood, C. (2002), 'The risk game and the blame game', Government and Opposition 37(1): 15-37.

Hood, C. (2007), 'What happens when transparency meets blame-avoidance?', Public Management Review 9(2): 191-210.

Hood, C. (2011), The Blame Game: Spin, Bureaucracy, and Self-Preservation in Government, Princeton, NJ: Princeton University Press.

Hood, C. and R. Dixon (2015), 'What We Have to Show for 30 Years of New Public Management: Higher Costs, More Complaints', Governance 28(3): 265-367.

Hood, C., W. Jennings, R. Dixon, B. Hogwood and C. Beeston (2009), 'Testing times: exploring staged responses and the impact of blame management strategies in two examination fiasco cases', European Journal of Political Research 48(6): 695-722.

Hood, C. and H. Rothstein (2001), 'Risk regulation under pressure: problem solving or blame shifting?', Administration \& Society 33(1): 21-53.

Horn, M.J. (1995), The Political Economy of Public Administration: Institutional Choice in the Public Sector, Cambridge, England and New York, NY: Cambridge University Press.

Jacobs, A.M. and R.K. Weaver (2015), 'When policies undo themselves: self-undermining feedback as a source of policy change', Governance 28(4): 441-457.

Jenni, S. (2015), 'Switzerland's regulatory European integration: between Tacit Consensus and Noisy Dissensus', Swiss Political Science Review 21(4): 508-537.

Jensen, C. and P.B. Mortensen (2014), 'Government responses to fiscal austerity: the effect of institutional fragmentation and partisanship', Comparative Political Studies 47(2): 143-170.

Johnson, J. (2014), 'Models among the political theorists', American Journal of Political Science 58(3): $547-560$.

Kingdon, J.W. (1995), Agendas, alternatives, and public policies, 2nd edn., New York: HarperCollins.

König, P.D. and G. Wenzelburger (2014), 'Toward a theory of political strategy in policy analysis', Politics \& Policy 42(3): 400-430.

Lyons, J. and W.P. Jaeger (2014), 'Who do voters blame for policy failure? Information and the Partisan assignment of blame', State Politics \& Policy Quarterly 14(3): 321-341.

Mayhew, D.R. (1974), Congress: The Electoral Connection, New Haven: Yale University Press.

McGraw, K.M. (1991), 'Managing blame: an experimental test of the effects of political accounts', The American Political Science Review 85(4): 1133-1157.

Mercer, J. (2005), 'Prospect theory and political science', Annual Review of Political Science 8(1): 1-21.

Mondak, J.J. (1993), 'Source cues and policy approval: the cognitive dynamics of public support for the reagan agenda', American Journal of Political Science 37(1): 186.

Mortensen, P.B. (2012), 'It's the Central Government's Fault': elected regional officials' use of blame-shifting rhetoric', Governance 25(3): 439-461. 
Mortensen, P.B. (2013a), '(De-)centralisation and attribution of blame and credit', Local Government Studies 39(2): 163-181.

Mortensen, P.B. (2013b), 'Public sector reform and blame avoidance effects', Journal of Public Policy 33 (02): 229-253.

Moynihan, D.P. (2012), 'Extra-network organizational reputation and blame avoidance in networks: The Hurricane Katrina example', Governance 25(4): 567-588.

Nielsen, P.A. and M. Baekgaard (2015), 'Performance information, blame avoidance, and politicians' attitudes to spending and reform: evidence from an experiment', Journal of Public Administration Research and Theory 25(2): 545-569.

Page, B.I., R.Y. Shapiro and G.R. Dempsey (1987), 'What moves public opinion?’, The American Political Science Review 81(1): 23-43.

Pal, L.A. and R.K. Weaver (2003), The government taketh away: The politics of pain in the United States and Canada, Washington, D.C.: Georgetown University Press.

Pierson, P. (1994), Dismantling the welfare state?: Reagan, Thatcher, and the politics of retrenchment, Cambridge, England, New York: Cambridge University Press.

Pierson, P. (1996), 'The new politics of the welfare state', World Politics 48(2): 143-179.

Powell, G.B. and G.D. Whitten (1993), 'A cross-national analysis of economic voting: taking account of the political context', American Journal of Political Science 37(2): 391.

Ross, F. (2000), 'Framing welfare reform in affluent societies: rendering restructuring more palatable?', Journal of Public Policy 20(2): 169-193.

Sager, F. and M. Hinterleitner (2016), 'How do credit rating agencies rate? An implementation perspective on the assessment of austerity programs during the European debt crisis', Politics \& Policy (forthcoming).

Schmidt, V.A. (2001), 'The politics of economic adjustment in France and Britain: when does discourse matter?', Journal of European Public Policy 8(2): 247-264.

Soss, J.O. and S.F. Schram (2007), 'A public transformed? Welfare reform as policy feedback', American Political Science Review 101(1): 111-127.

Streeck, W. and A. Schäfer (2013), Politics in the Age of Austerity, Cambridge, UK: Polity.

Strøm, K. (1990), 'A behavioral theory of competitive political parties', American Journal of Political Science 34(2): 565-598.

Sulitzeanu-Kenan, R. (2010), 'Reflection in the shadow of blame: when do politicians appoint commissions of inquiry?', British Journal of Political Science 40(3): 613-634.

Sulitzeanu-Kenan, R. and C. Hood (2005), 'Blame avoidance with adjectives?: motivation, opportunity, activity and outcome'. Paper for ECPR Joint Sessions, April 14-20, Granada.

Sulitzeanu-Kenan, R. and L. Sheffer (2011), 'A formal model of social blame in political context'. Paper presented at the 69th Annual Midwest Political Science Association (MPSA) Conference, March 31-April 3, Chicago, IL.

Vis, B. (2009), 'Governments and unpopular social policy reform: biting the bullet or steering clear?', European Journal of Political Research 48(1): 31-57.

Vis, B. (2016), 'Taking stock of the comparative literature on the role of blame avoidance strategies in social policy reform', Journal of Comparative Policy Analysis: Research and Practice 18(2): 122-137.

Walgrave, S. and P. van Aelst (2006), 'The contingency of the mass media's political agenda setting power: toward a preliminary theory', Journal of Communication 56(1): 88-109.

Weaver, R.K. (1986), 'The politics of blame avoidance', Journal of Public Policy 6(4): 371-398.

Weaver, R.K. (1988), Automatic Government: The Politics of Indexation, Washington, DC: Brookings Institution.

Weaver, R.K. (2013), Policy Leadership and the Blame Trap: Seven Strategies for Avoiding Policy Stalemate'. Governance Studies, Brookings Institution, Washington, DC, March.

Wenzelburger, G. (2011), 'Political strategies and fiscal retrenchment: evidence from four countries', West European Politics 34(6): 1151-1184.

Wenzelburger, G. (2014), 'Blame avoidance, electoral punishment and the perceptions of risk', Journal of European Social Policy 24(1): 80-91.

Wenzelburger, G. and F. Hörisch (2016), 'Framing effects and comparative social policy reform: comparing blame avoidance evidence from two experiments', Journal of Comparative Policy Analysis: Research and Practice 18(2): 157-175. 